Article

\title{
Radial Movement of Minerals in the Trunks of Standing Japanese Cedar (Cryptomeria Japonica D. Don) Trees in Summer by Tracer Analysis
}

\author{
Katsushi Kuroda*(D), Kenichi Yamane and Yuko Itoh \\ Forestry and Forest Products Research Institute, 1 Matsunosato, Tsukuba, Ibaraki 305-8687, Japan; \\ coxken24@gmail.com (K.Y.); yuko106@affrc.go.jp (Y.I.) \\ * Correspondence: kurodak@affrc.go.jp; Tel.: +81-29-829-8300
}

Received: 29 April 2020; Accepted: 15 May 2020; Published: 17 May 2020

\begin{abstract}
The radial movement of minerals in tree trunks is a widely accepted function of ray parenchyma cells, but there is little experimental evidence for this. We previously obtained experimental data showing that the parenchyma cells were the site of the radial mineral movement in Japanese cedar (Cryptomeria japonica D. Don) trunks in winter. Therefore, the aim of this study was to answer two remaining questions: do parenchyma cells move minerals via active transport or passive diffusion and how do seasonality and the injection duration affect the radial movement of minerals. To analyze this, we compared mineral movement in living standing Japanese cedar trees with heartwood in which the trunk had been left untreated or freeze-thawed with liquid nitrogen to kill the living cells. A solution of a stable isotope of cesium (Cs), as a tracer of mineral movement, was continuously injected into the outer sapwood of these normal and freeze-thaw-treated trees for an objective period, following which the trunk was freeze-fixed with liquid nitrogen. The $\mathrm{Cs}$ distribution in frozen samples was then analyzed by cryo-scanning electron microscopy/energy-dispersive X-ray spectroscopy. After 1 and 5 days of injection, the Cs detection area was almost the same among parenchyma cells and tracheid cell walls in the freeze-thaw-treated samples (without living cells) but was further toward the inner xylem in the parenchyma cells than the tracheids in the normal samples (with living cells), indicating that living parenchyma cells move Cs. Furthermore, after 5 days of injection, Cs in the tracheid cell walls was detected further toward the inner xylem in the normal samples than in the freeze-thaw-treated samples, indicating that Cs is exuded from the parenchyma cells into the tracheid cell walls. Together, these results suggest that the radial movement of minerals in standing Japanese cedar trees occurs through a combination of active transport by parenchyma cells and diffusion in the cell walls.
\end{abstract}

Keywords: cesium; cryo-scanning electron microscopy; energy dispersive X-ray spectroscopy; cryo-SEM/EDX; xylem

\section{Introduction}

The transport of mineral nutrition to all of the tissues is fundamental for the longevity of trees. The trunks of trees have two types of transport systems: the apoplasmic system, which moves minerals from the roots via conduit cells (dead cells; e.g., [1,2]), and the symplasmic system, which involves radial movement via living cells (e.g., [3]). It is generally accepted that ray parenchyma cells in the tree trunk are involved in this radial movement, but there is currently little experimental evidence from analyses of the inside of living tree trunks to support this [4-13].

Analysis of the movement of chemicals in the trunks of standing trees is challenging because the chemicals inside a tree are dissolved in solution and thus chemical changes from the standing 
condition easily occur via pressure changes when a tree is cut down or drying out. Therefore, to study the physiology of standing trees, Kuroda et al. [14-16] proposed the use of a novel combination of a unique sampling method and the direct analysis of freeze-fixed trunk samples from standing trees proved very effective for analyzing the distributions of water and chemicals.

In our previous research, we injected a stable isotope of cesium (Cs) into the trunks of standing Japanese cedar (Cryptomeria japonica D. Don) trees as a tracer of mineral movement, which allowed us to analyze the ionized Cs distribution of water-hydrated samples at the cellular level using cryo-scanning electron microscopy/energy-dispersive X-ray spectroscopy (cryo-SEM/EDX) [16]. This showed that after a 4 days injection period, Cs was detected in the ray parenchyma cell walls and lumina in the inner part of the xylem rather than the tracheid cell walls and lumina, suggesting that Cs moved rapidly from the outer sapwood to the inner sapwood via ray parenchyma cells rather than tracheids. However, while we concluded that ray parenchyma cells were the site of Cs movement in Japanese cedar trees, we were unable to confirm whether minerals were actively transported by ray parenchyma cells or passively move by diffusion [16] (Kuroda et al., 2018).

Short-distance symplasmic connections via ray parenchyma cells have been proposed using fluorescent tracers in the internodal tissues of tomato (Solanum lycopersicum) [6], in the phloem and xylem of stems of Eucalyptus saligna [13], and in the branches of Acer pseudoplatanus L. and Populus tremula $\times$ P. tremuloides Michx. [11]. In addition, long-distance radial transfer from the sapwood to heartwood of the trunks of Japanese cedar trees via active transport through the ray parenchyma cells has been reported $[9,10]$. However, while these studies have demonstrated the existence of radial mineral transport, no direct evidence of radial movement via ray parenchyma cells was provided. Furthermore, our previous finding that Cs was not moved into the inner heartwood of Japanese cedar trees differs from other results for the same species, which showed that rubidium ( $\mathrm{Rb}$ ) that had been injected in the outer sapwood was detected in the inner heartwood [10] and radiocesium that had been accidentally injected into Japanese cedar trees in the Fukushima area was distributed in the heartwood [17] and continuously accumulated there [18]. These differences may have resulted from seasonality in the activity of the ray parenchyma cells [19] (analyses were undertaken in February by Kuroda et al. [16], May by Okada et al. [10], and long days after March 2011 when the Fukushima Daiichi Nuclear Power Plant accident occurred by Kuroda et al. [17]) or variation in the injection duration.

The aim of this study was to reveal whether the radial movement of minerals in the trunks of trees is performed by ray parenchyma cells and to clarify the effects of seasonality and the duration of the injection treatment to further our understanding of mineral movement in standing trees.

\section{Materials and Methods}

\subsection{Plant Materials}

Japanese cedar trees planted at the Chiyoda nursery of the Forestry and Forest Products Research Institute (Kasumigaura, Ibaraki, Japan) were used in this study (Table 1), all of which had developed colored heartwood.

In order to compare the behavior of Cs movement in the trunks of standing Japanese cedar trees that contained living parenchyma cells (normal trees) and that without living cells in the standing tree trunk, four trees were selected for freeze-thaw treatment of the trunk to remove living parenchyma cells from part of the living standing tree. This treatment involved attaching a watertight receptacle over the trunk of the tree approximately $1 \mathrm{~m}$ above the ground at the site where Cs solution would be injected. This receptacle was filled with liquid nitrogen $\left(\mathrm{LN}_{2}\right)$ and the trunk was allowed to freeze for approximately $30 \mathrm{~min}$, after which it was left overnight $\left(\mathrm{LN}_{2}\right.$ vaporized approximately 5 min after stopping the $\mathrm{LN}_{2}$ supply). The receptacle was then refilled with $\mathrm{LN}_{2}$ the next day or 5 days later and left for either $1 \mathrm{~h}$ or several days before Cs injection started, which was dependent on the weather condition. 
In this study, intermediate wood was defined as the zone inside the sapwood that developed an easily distinguishable white color under the frozen condition, as described in Kuroda et al. [16], and sapwood, intermediate wood, and heartwood were distinguished by color [14,20,21].

Table 1. Basic information on the samples.

\begin{tabular}{|c|c|c|c|c|c|c|}
\hline \multirow[b]{2}{*}{$\begin{array}{c}\text { Tree } \\
\text { Number }\end{array}$} & \multirow[b]{2}{*}{ Age } & \multirow[b]{2}{*}{$\begin{array}{l}\text { Tree Height } \\
\text { (m) }\end{array}$} & \multirow[b]{2}{*}{$\begin{array}{c}\text { Girth at } 1.2 \\
\mathrm{~m}(\mathrm{~cm})\end{array}$} & \multicolumn{3}{|c|}{ Injection } \\
\hline & & & & $\begin{array}{l}\text { Period of } \\
\text { Injection }\end{array}$ & $\begin{array}{l}\text { Starting Date } \\
\text { (D/M/Y) }\end{array}$ & $\begin{array}{c}\text { Harvesting } \\
\text { Date (D/M/Y) }\end{array}$ \\
\hline \multicolumn{7}{|c|}{ Injection after freeze-thawing } \\
\hline \multirow[t]{2}{*}{167} & 38 & 15.7 & 49.0 & 1 day & 26/07/2018 & 27/07/2018 \\
\hline & & & & 4 days & 23/07/2018 & $27 / 07 / 2018$ \\
\hline \multirow[t]{2}{*}{169} & 38 & 15.7 & 48.0 & 1 day & 26/07/2018 & $27 / 07 / 2018$ \\
\hline & & & & 4 days & 23/07/2018 & $27 / 07 / 2018$ \\
\hline \multirow[t]{2}{*}{173} & 38 & 16.5 & 43.0 & 1 day & $11 / 09 / 2018$ & $12 / 09 / 2018$ \\
\hline & & & & 5 days & 07/09/2018 & $12 / 09 / 2018$ \\
\hline \multirow[t]{2}{*}{143} & 36 & 14.2 & 41.0 & 5 days & 05/08/2016 & $10 / 08 / 2016$ \\
\hline & \multicolumn{6}{|c|}{ Normal injection } \\
\hline \multirow[t]{3}{*}{137} & 35 & 14.6 & 46.0 & $3 \mathrm{~h}$ & 22/07/2015 & $22 / 07 / 2015$ \\
\hline & & & & 1 day & $21 / 07 / 2015$ & $22 / 07 / 2015$ \\
\hline & & & & 5 days & $17 / 07 / 2015$ & $22 / 07 / 2015$ \\
\hline \multirow[t]{2}{*}{ B11-4 } & 10 & 7.3 & 52.4 & $3 \mathrm{~h}$ & $22 / 07 / 2015$ & $22 / 07 / 2015$ \\
\hline & & & & 1 day & 21/07/2015 & $22 / 07 / 2015$ \\
\hline \multirow[t]{2}{*}{171} & 38 & 17.5 & 55.0 & 1 day & 26/07/2018 & 27/07/2018 \\
\hline & & & & 4 days & $23 / 07 / 2018$ & $27 / 07 / 2018$ \\
\hline \multirow[t]{2}{*}{177} & 38 & 15.8 & 45.0 & 1 day & $11 / 09 / 2018$ & $12 / 09 / 2018$ \\
\hline & & & & 5 days & 07/09/2018 & $12 / 09 / 2018$ \\
\hline 101 & 35 & 14.7 & 44.5 & 60 days & $13 / 07 / 2015$ & $11 / 09 / 2015$ \\
\hline B11-3 & 10 & 7.1 & 51.4 & 60 days & $13 / 07 / 2015$ & $11 / 09 / 2015$ \\
\hline
\end{tabular}

The age was counted at a stump (approximately $20 \mathrm{~cm}$ height). The starting time of injection was between 9:00 and 13:00, and the ending time of injection was between 9:00 to 14:00.

\subsection{Fluorescence Microscopic Examination of Cell Morphology}

Fluorescence microscopy was used to confirm whether the parenchyma cells in the trunks of normal and freeze-thaw-treated tree were alive or dead. Small blocks $(2 \mathrm{~cm} \times 2 \mathrm{~cm} \times 2 \mathrm{~cm})$ were collected from the outer sapwood of the trunks of normal and freeze-thaw-treated trees at approximately $1.2 \mathrm{~m}$ above the ground. The blocks were immediately fixed in a $4 \%(w / v)$ solution of glutaraldehyde in $0.1 \mathrm{M}$ phosphate buffer ( $\mathrm{pH} 7.2$ ) and kept in a refrigerator until use. For the analysis, the samples were cut into radial sections of approximately $40 \mu \mathrm{m}$ thickness using a sliding microtome (TU-213; Yamatokohki, Saitama, Japan) and washed with distilled water. The radial sections were then stained with a $0.0001 \%$ $(w / v)$ aqueous solution of $4^{\prime}, 6$-diamidino-2-phenylindole (DAPI) to observe the nuclei [22], and the nuclei and cytosol were examined under a fluorescence microscope with a U-MWU2 filter cube (BX41; Olympus Tokyo, Japan).

\subsection{Preparation of the Cs Solution for Standing Tree Injection}

A cesium chloride solution (final concentration, $1.0 \mathrm{M}$ ) was prepared in aqueous acid fuchsin (final concentration, $0.1 \%$ w/v; Nacalai Tesque Inc., Kyoto, Japan) and used as the Cs tracer of mineral movement in the standing tree trunks, following Kuroda et al. [16]. Acid fuchsin is a red dye that is often used to detect the water conduit tissues of tree trunks [23-27], which we have successfully used to readily identify the solution-conduit area in frozen trunk samples with the naked eye [16].

\subsection{Cs Injection and Sample Collection}

Cs injection and sample collection were performed according to Kuroda et al. [16]. The outer bark was removed with an approximately $2 \mathrm{~cm}$ diameter circle from the trunk of each tree approximately 
$1 \mathrm{~m}$ above the ground and small holes (approximately $3 \mathrm{~mm}$ and $0.1-0.5 \mathrm{~cm}$ deep) were drilled into the sapwood. Each hole was separated by $90^{\circ}$ where three injection points were used or $120^{\circ}$ where two injection points were used. The parts on the side without the drilled holes were used as a control. A 500-mL or 1000-mL polyethylene bottle filled with Cs solution was set on the trunk of each sample tree approximately $20 \mathrm{~cm}$ above each drilled hole and the solution was injected into the drilled hole through a plastic tube (Tygon LMT-55; Saint-Gobain, Tokyo, Japan) that had a stainless-steel tube $(2.84 \mathrm{~mm})$ attached to the end. The solution was injected continuously for an objective period (Table 1), with injection stopping $<20$ min before the trunk was frozen (see below). For longer injection periods, a new solution was added to the plastic bottle several times during the injection period to prevent the bottle from emptying.

Following injection, packaging tape was wrapped around the sampling part of the tree trunk to prevent leakage of the liquid and a watertight receptacle was then attached to the tree trunk to cover the sampling part [16]. The receptacle was then filled with $\mathrm{LN}_{2}$, the trunk was frozen for approximately $30 \mathrm{~min}$, and the tree was felled. Serial discs (1-cm-thick cross-sections) were cut from the frozen part of the trunk, immediately immersed in $\mathrm{LN}_{2}$, and stored at $-80^{\circ} \mathrm{C}$ in a deep freezer.

\subsection{Cryo-SEM/EDX}

Frozen discs that had been obtained $1-3 \mathrm{~cm}$ above the Cs injection hole were used for cryo-SEM/EDX analysis according to Kuroda et al. [16]. Briefly, approximately 3-mm-wide strips that passed through the red area of sapwood and pith were taken from the frozen discs and cut into small blocks. The fresh transverse surfaces of these blocks were then smoothly cut using a cryostat (HM505E (MICROM International GmbH, Walldorf, Germany), CM 1100 (Leica Microsystems, Buffalo Grove, IL, USA), or Cryostar NX70 (Thermofisher Scientific, Tokyo, Japan)) at approximately $-30{ }^{\circ} \mathrm{C}[14,16]$ (Kuroda et al., 2009, 2018). The blocks were attached to a specimen holder and transferred to a cryo-SEM/EDX system (JSM6510A, JED-2300; JEOL, Tokyo, Japan). Secondary electron (SE) images were obtained at acceleration voltages of $3 \mathrm{kV}$ and $15 \mathrm{kV}$ with gold coating in the cryo-SEM/EDX system, and the characteristic $X$-rays were detected at an acceleration voltage of $15 \mathrm{kV}$. Several points on each SE image were selected for the point analysis, and X-rays were collected for 200-300 s at each point. All observations and analyses were performed using the Analysis Station software, ver. 3.8 (JEOL, Tokyo, Japan). The Cs-L $\alpha$ peak ( $4.286 \mathrm{keV}$ ) at each point was carefully checked and defined in terms of the presence of Cs. This analysis was conducted in a radial direction from the acid fuchsin-stained red area toward the pith. The tracheid lumen (TL), which was filled with water, tracheid-tracheid cell wall (TW), parenchyma-tracheid and parenchyma lumen (PL), and parenchyma-parenchyma cell wall (PW) were analyzed in several areas in each sample block [16].

\subsection{Cs Concentration}

The Cs concentration of a normal tree was analyzed from the bark to the heartwood by inductively coupled plasma mass spectrometry (ICP-MS), according to Kuroda et al. [16]. Strips (2 mm wide) were cut from the frozen discs and lyophilized in a freeze dryer (FD-1000; EYELA, Tokyo, Japan). The dried strips were then cut into several pieces from the inner bark to the heartwood. Each piece was weighed, placed in a Teflon bottle containing nitric acid $(1000 \mu \mathrm{L}$, Ultrapur-100, Nitric acid 1.42; KANTO CHEMICAL, Tokyo, Japan), and left to stand overnight. The Teflon bottles were then set in a high-pressure decomposition stainless container (HU25; San-ai Kagaku, Nagoya, Japan) and the samples in the bottles were dissolved at $110^{\circ} \mathrm{C}$ for $6 \mathrm{~h}$. After digestion, each solution was poured into a plastic bottle containing ultrapure water to give approximately $50 \mathrm{~mL}$ total solution. This solution was then filtered through a $0.45-\mu \mathrm{m}$ membrane filter (DISMIC-25HP; ADOVANTEC, Tokyo, Japan) and the sample was diluted approximately $1-5000$-fold using nitric acid solution $\left(2 \% \mathrm{HNO}_{3}\right)$. The $\mathrm{Cs}$ concentration in the sample was then measured by ICP-MS (ICP-MS 7500 cs; Agilent Technologies, Palo Alto, CA, USA), using cerium (Ce) as an internal standard. A reference material (SPS-SW1; SPS, Oslo, Norway) was also tested to assess the accuracy of the measurements. 


\section{Results}

\subsection{Parenchyma Cell Structure of Normal and Freeze-Thaw-Treated Samples}

We used fluorescence microscopy and cryo-SEM to compare the morphology of the parenchyma cells in normal and freeze-thaw-treated samples. Fluorescence microscopic observation showed that the ray parenchyma cells in the normal samples had elliptical nuclei and granular contents in their cytoplasm, whereas those in the freeze-thaw-treated samples had no or deformed nuclei and some autofluorescent materials attached in the lumen (Figure 1A,D). Cryo-SEM observation further showed that the ray parenchyma cells in the normal samples had cellular contents with water, whereas those in the freeze-thaw-treated samples exhibited dehydration of the cytosol or the accumulation of broken materials in the cytosol (Figure $1 \mathrm{~B}, \mathrm{C}, \mathrm{E}, \mathrm{F}$ ).
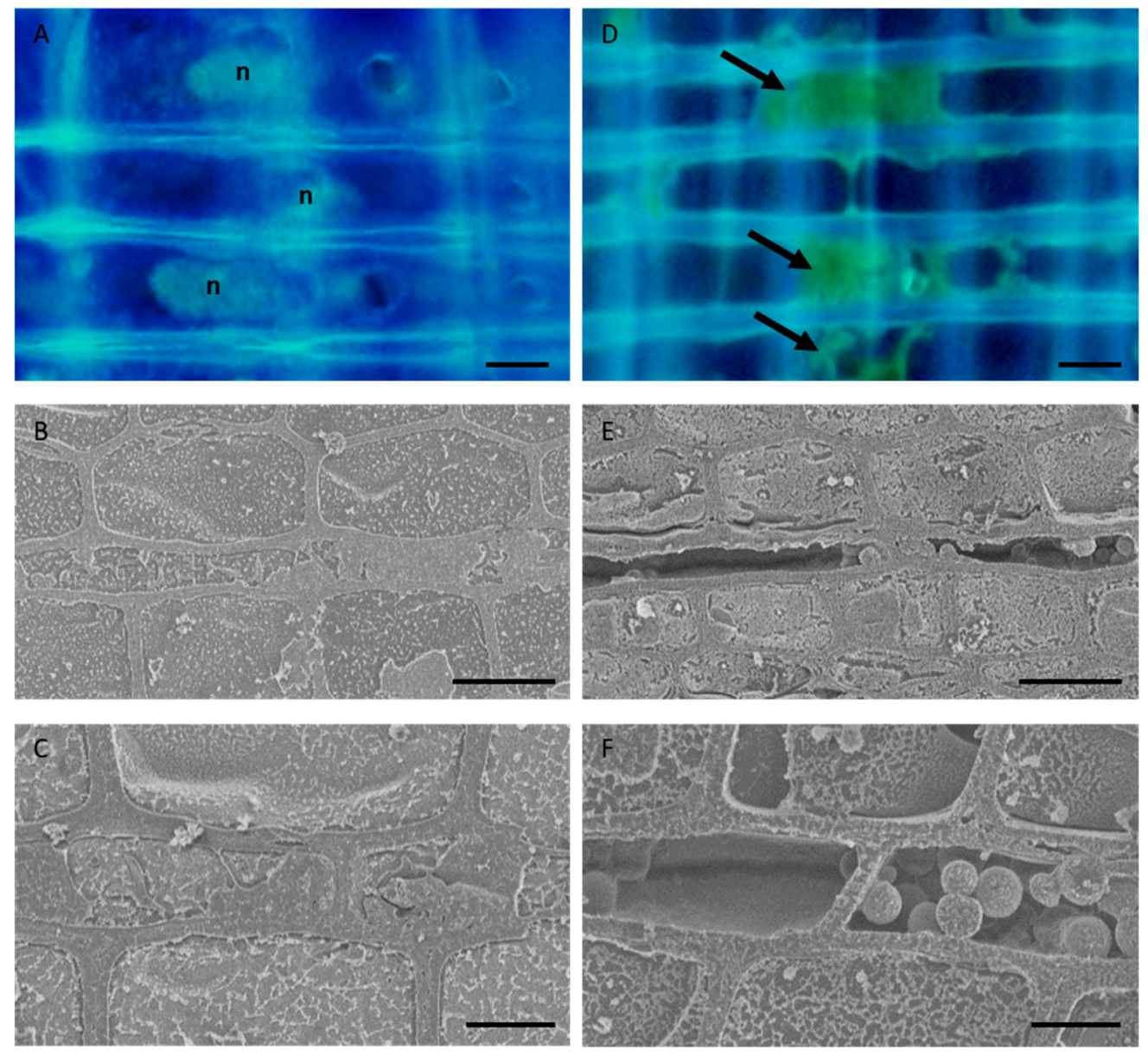

Figure 1. Morphology of the parenchyma cells in the sapwood of normal and freeze-thaw-treated Japanese cedar (Cryptomeria japonica) tree trunks. (A,D) Fluorescence micrographs of radial sections stained with 4', 6-diamidino-2-phenylindole (DAPI). (B,C,E,F) Cryo-scanning electron micrographs of the transverse plane of frozen-hydrated samples. It can be seen that living parenchyma cells in the normal tree trunk have elliptical nuclei and cellular contents $(\mathbf{A}-\mathbf{C})$, while the parenchyma cells in the freeze-thaw-treated samples have no or deformed nuclei, contain some autofluorescent material (arrows) in the lumina (D), and exhibit dehydration or the accumulation of some broken materials in the cytosol (E,F). n, nuclei. Bars, $10 \mu \mathrm{m}$.

\subsection{Cs Distribution in the Freeze-Thaw-Treated Samples}

We investigated whether a lack of living parenchyma cells affected mineral movement in the trunk using freeze-thaw-treated trees. Analysis of the Cs detection area in the freeze-thaw-treated 
samples showed that the red staining of the acid fuchsin had spread radially through several annual rings from the outermost annual ring (Figure 2). The Cs peaks in the tracheid lumen (TL) were almost identical to the red-colored area in all samples. The Cs peaks in the cell wall between tracheids (TW), ray parenchyma cell lumen (PL), and cell wall of ray parenchyma cell (PW) were detected in almost the same area within a given sample and were further toward the inner xylem in samples that had been injected for 4 or 5 days compared with those that had been injected for 1 day within the same tree in all samples.

167_1day
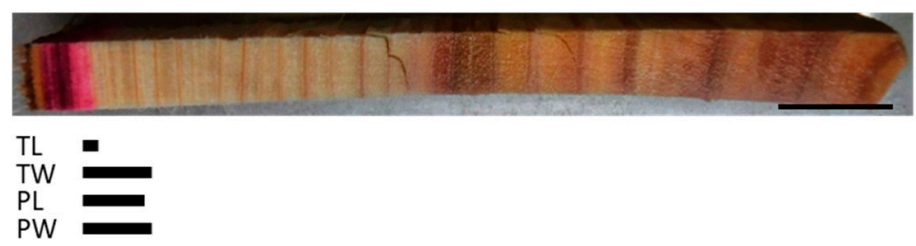

167_4days
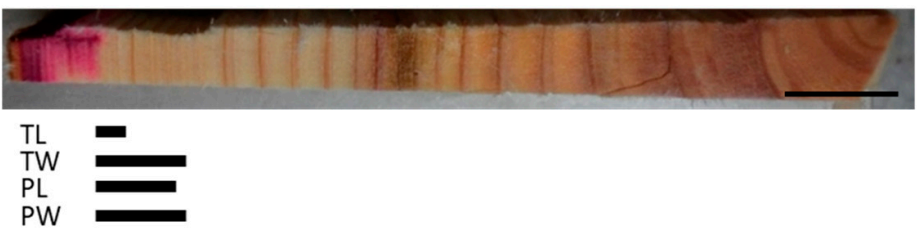

169_1day
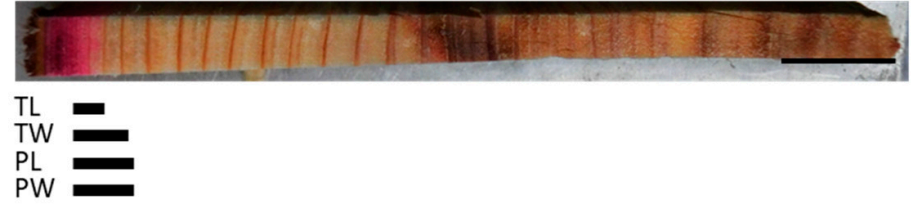

169_4days
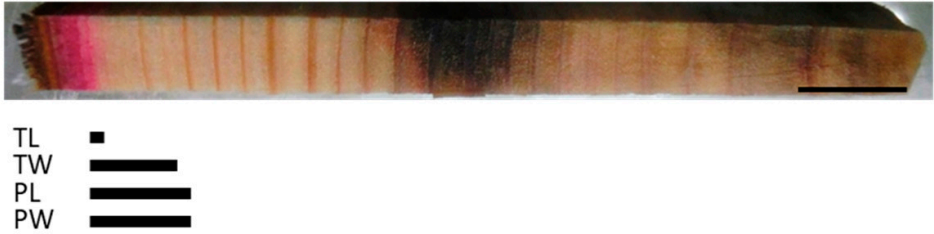

173_1day

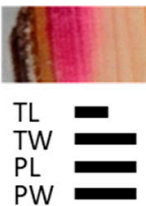

173_5days
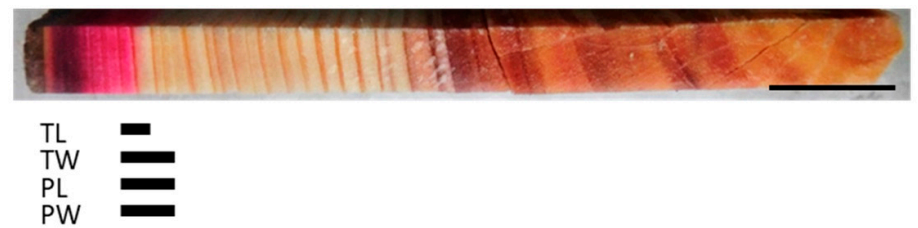

143_5days

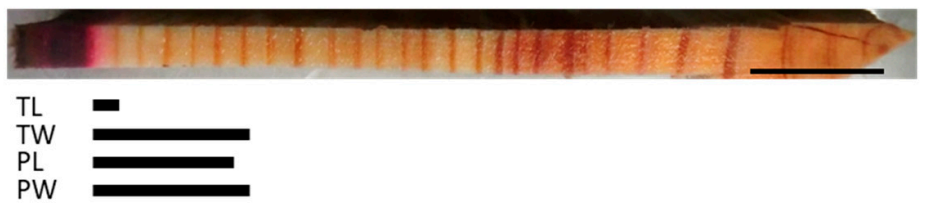

Figure 2. Schematic representation of radially distributed cesium (Cs) in the xylem of freeze-thaw-treated Japanese cedar (Cryptomeria japonica) trees after 1 day, 4 days, or 5 days of injection, as observed using cryo-scanning electron microscopy/energy-dispersive X-ray spectroscopy (cryo-SEM/EDX). Bars below the sample image represent the areas where Cs was detected. TL, tracheid lumen; TW, cell wall between tracheids; PL, ray parenchyma cell lumen; PW, cell wall of ray parenchyma cell. Bars on the sample images, $1 \mathrm{~cm}$. 


\subsection{Cs Distribution in the Normal Samples}

In all of the normal samples, the red area stained by acid fuchsin was distributed over a small area in the outer sapwood and clear Cs peaks were detected at all of the points that were analyzed in this area (Figure 3). Along a radial position from this area to the inner xylem, different Cs peaks were detected according to the injection duration and/or cell structures. In the TL of all samples, Cs was detected in the dark red-colored area. In the 3-h injected samples, the Cs peak in the TW was detected in the same area as in the TL or approximately one and a half annual rings from the red-colored border, while those in the PL and PW were detected in the dark and light red-colored area or approximately one and a half annual rings from the red-colored border. In the 1-day injected sample, the Cs peak in the TW was detected beyond the detection area in the TL, while those in the PL and PW were detected even further toward the inner xylem. In the 4- or 5-day injected samples, the Cs peaks in the TW were detected from the red area stained by acid fuchsin to the middle part of the sapwood, as well as in some parts of the intermediate wood, while those in the PL and PW were detected in the sapwood, the intermediate wood, and in a few annual rings in the outer heartwood.

To examine the effect of a longer injection period, we injected the Cs solution for 60 days (Figure 4). This resulted in the red area stained by acid fuchsin spreading throughout the sapwood radially from the injection point toward the pith but stopping at the border between the sapwood and the intermediate wood. By contrast, Cs was detected in the intermediate wood and the heartwood close to the pith in all structures, though it was further toward the inner xylem in the cell walls than in the lumina of both the tracheids and parenchyma cells. No Cs was detected in the TL in some parts of the intermediate wood and the heartwood. 
137_3h

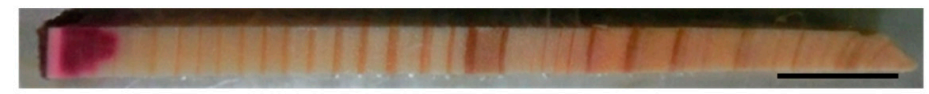

TL $=$
TW
PL

137_1day

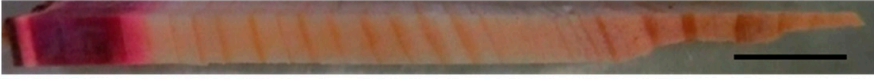

$\mathrm{TL}$
$\mathrm{TW}$
$\mathrm{PL}$

137_5days
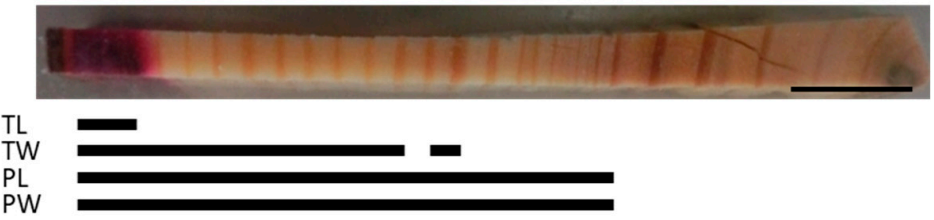

B11-4_3h
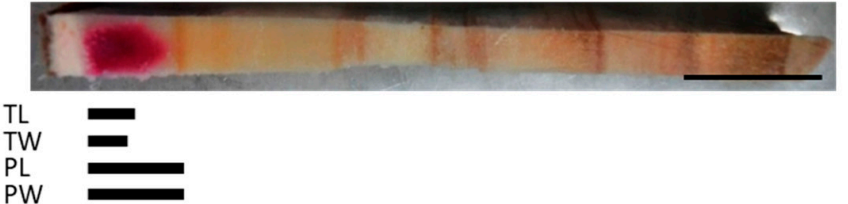

B11-4_1day
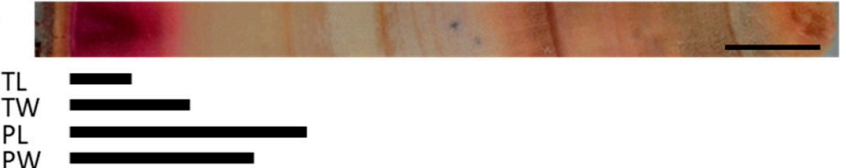

171_1day

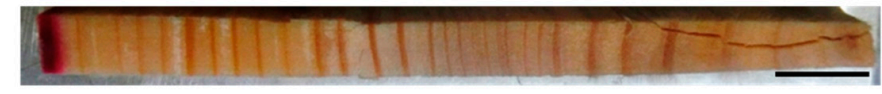

TL

TW

$\mathrm{PL}=$

171 4days
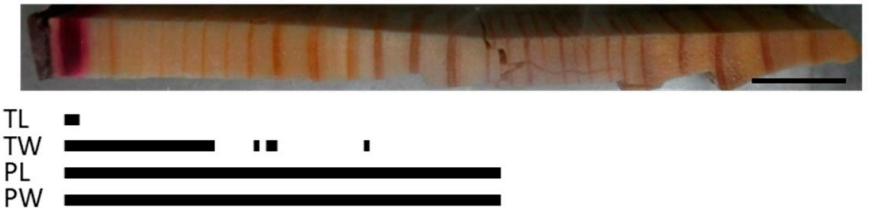

177_1day
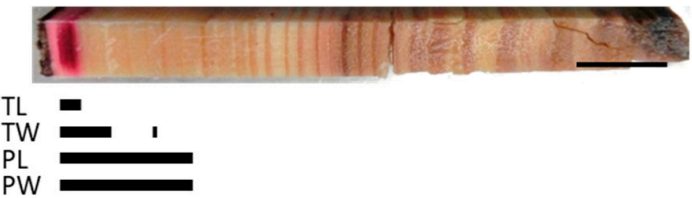

177 5days
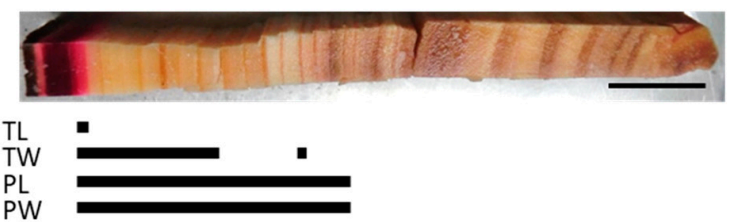

Figure 3. Schematic representation of radially distributed cesium (Cs) in the xylem of normal Japanese cedar (Cryptomeria japonica) trees after $3 \mathrm{~h}, 1$ day, 4 days, or 5 days of injection, as observed using cryo-scanning electron microscopy/energy-dispersive X-ray spectroscopy (cryo-SEM/EDX). Abbreviations are the same as described in Figure 2. 

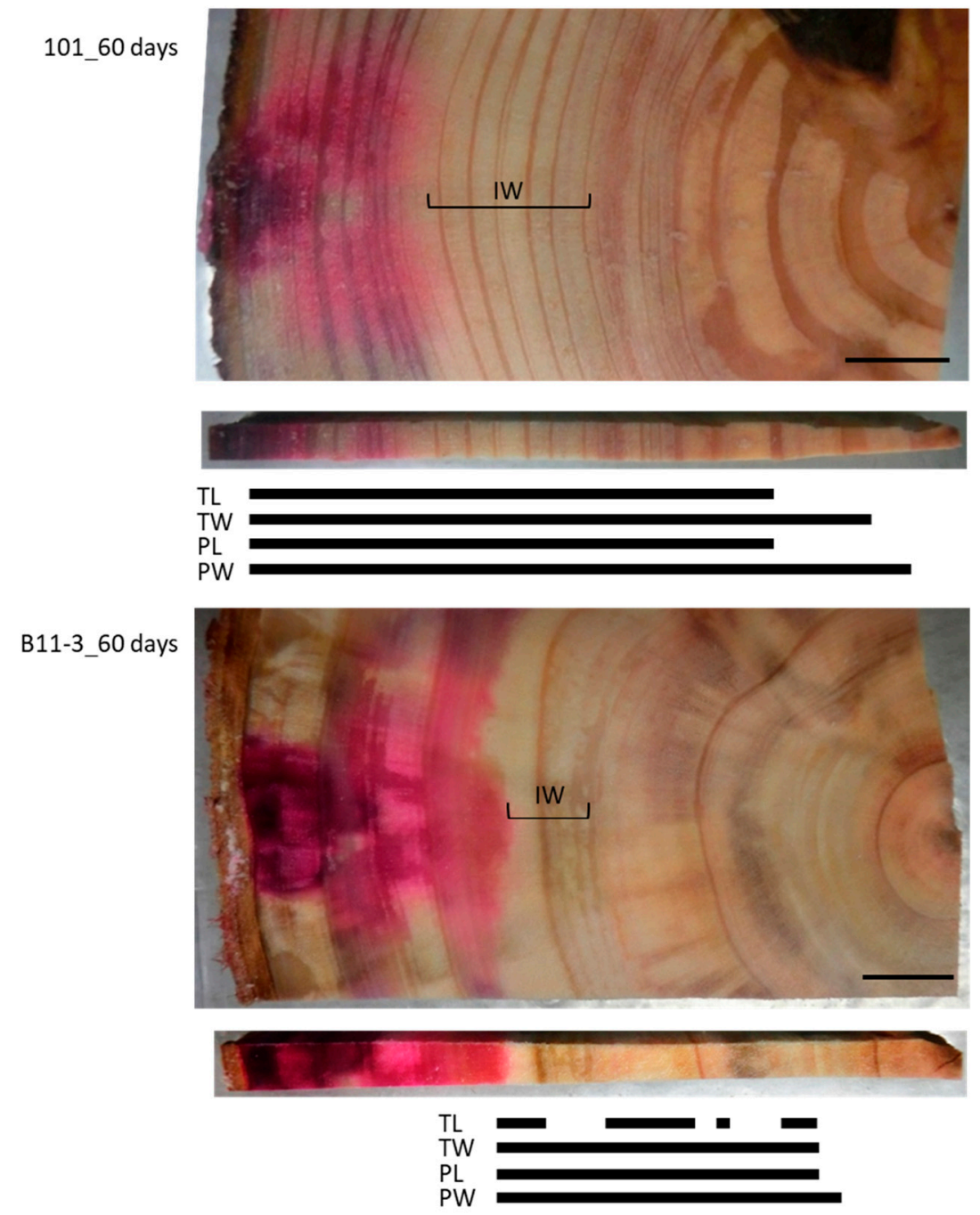

Figure 4. Schematic representation of radially distributed cesium (Cs) in the xylem of normal Japanese cedar (Cryptomeria japonica) trees after 60 days of injection, as observed using cryo-scanning electron microscopy/energy-dispersive X-ray spectroscopy (cryo-SEM/EDX). IW, intermediate wood area; other abbreviations are the same as described in Figure 2.

\subsection{Quantitative Analysis by ICP-MS}

To complement the qualitative data obtained using cryo-SEM/EDX, we examined the quantitative Cs distribution after $3 \mathrm{~h}, 1$ day, and 5 days of injection of the tree 137 using ICP-MS (Figure 5). The control samples contained a Cs concentration of approximately $10 \mu \mathrm{g} / \mathrm{kg}$ or less. The Cs concentration was high in the outer sapwood in the 3-h injected tree, in the outer and middle part of the sapwood in the 1-day injected tree, and from the sapwood to the outermost annual ring of the heartwood in the 5-day injected tree. 


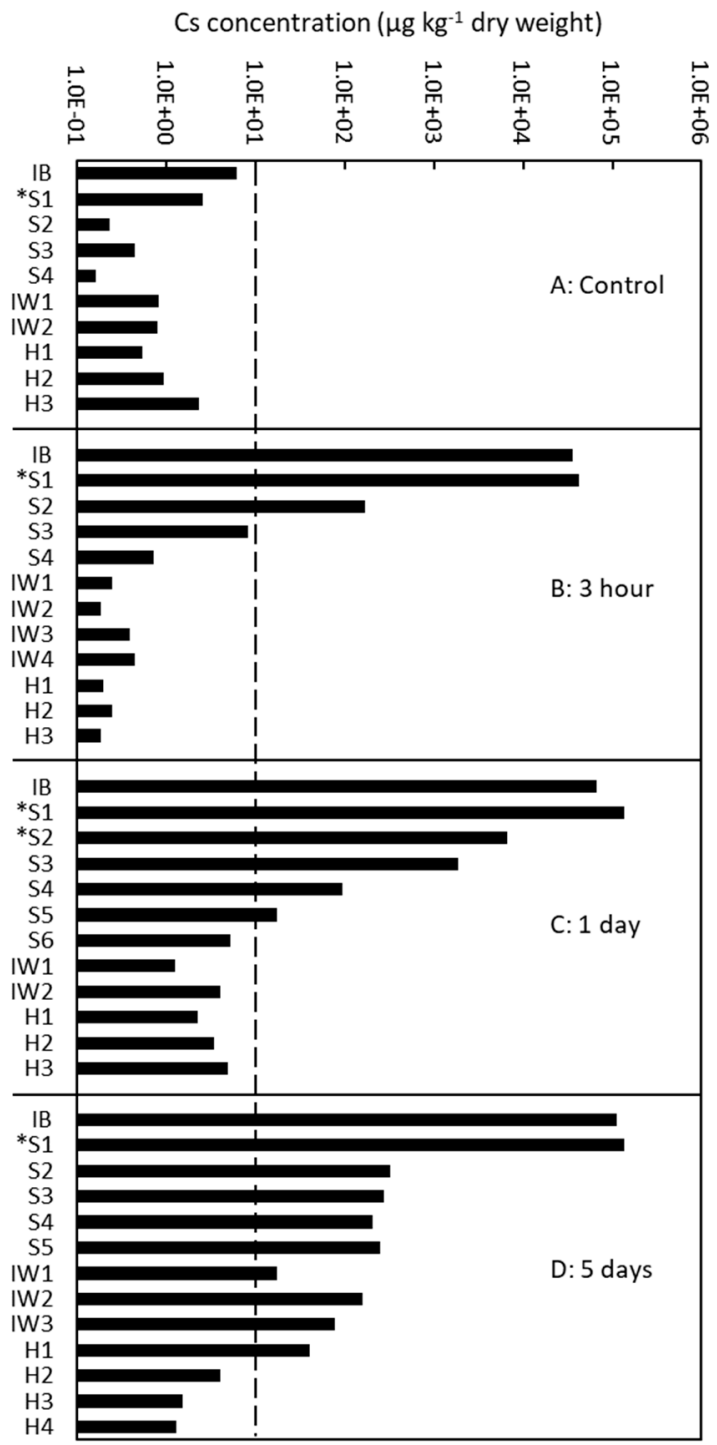

Figure 5. Quantitative analysis of the radial distribution of cesium (Cs) in the xylem of Japanese cedar (Cryptomeria japonica) trees using inductively coupled plasma mass spectrometry (ICP-MS) after (A) no injection (control); (B) $3 \mathrm{~h}$ of injection; (C) 1 day of injection; and (D) 5 days of injection in Tree 137. IB, inner bark; S1-S6, sapwood from the outer (S1) to inner (S6) parts; S with asterisk, sapwood with red coloration stained by acid fuchsin; IW1-4, intermediate wood from the outer (IW1) to inner (IW4) parts; and HW1-4, heartwood from the outer $(\mathrm{H} 1)$ to inner $(\mathrm{H} 4)$ parts.

\section{Discussion}

\subsection{Mechanism of Radial Movement in the Trunks of Standing Japanese Cedar Trees}

The ray parenchyma cells in trees have many putative functions, including the radial movement of minerals in the tree trunk. However, while many studies have been conducted to verify this function, few have provided direct evidence of it in standing living trees (e.g., [9-11]). Therefore, one big task that remains to be completed is to obtain experimental evidence of the mechanism of radial mineral movement in the trunk. We previously revealed that ray parenchyma cells are the site of mineral movement in standing Japanese cedar trunks through the use of a novel analysis of the cellular distribution of a mineral tracer [16]. However, several questions still remained about radial mineral movement, particularly in terms of whether this movement occurs through the activity of the cells or 
diffusion. Thus, it is necessary to distinguish active cell function from passive activity such as diffusion in standing trees to reveal the role of ray parenchyma cells in radial mineral movement.

In the present experiment, we compared the behavior of Cs movement in the trunks of standing Japanese cedar trees that contained living parenchyma cells (normal trees) and that had been treated with liquid nitrogen to kill the living cells in the standing tree trunk (freeze-thaw-treated trees). In general, freezing injury is known to destroy the cell membrane of plant cells, causing a loss of cell function and cell death [28-30], and an experimental freeze treatment has been shown to cause cell death in parenchyma cells of trees [31,32]. Here we found that the parenchyma cells in the normal samples had elliptical nuclei and granular contents of their cytoplasm, matching previous reports of living ray parenchyma cells, whereas those in the freeze-thaw-treated samples had no or deformed nuclei and dried or deformed cytosols, indicating that the cells had died $[16,19,20,22,33]$. Thus, this treatment succeeded in killing the parenchyma cells in part of the trunk of the standing trees while retaining the parenchyma cell walls, which are incapable of performing active transport.

Comparison of the Cs distribution in the normal and freeze-thaw-treated tree trunks after 1, 4 , or 5 days of injection demonstrated some interesting properties of mineral movement that are associated with living parenchyma cells (Figure 6). Firstly, we found that Cs in the ray parenchyma cells was distributed farther from the acid fuchsin-stained red area in the normal samples than in the freeze-thaw-treated samples, demonstrating that living parenchyma cells actively transport Cs-if this were not the case, the Cs distribution would be the same in the tracheids and parenchyma cells in both samples. Thus, the ray parenchyma cells appear to be involved in the active radial movement of minerals, and this occurs more rapidly than diffusion. Secondly, we found that the Cs distribution in the freeze-thaw-treated samples was the same in the tracheids and ray parenchyma cells, demonstrating that Cs diffusion occurs in the same way in the tracheid and parenchyma cell walls, despite the tracheids having a primary and secondary cell wall $[34,35]$ and the ray parenchyma cells only having a primary cell wall in Japanese cedar [36]. The lower level of diffusion that was observed in the tracheid lumen than in the other structures may have been caused by the loss of water from the tracheid lumina during the freeze-thaw treatment. Thirdly, we found that Cs in the tracheid cell walls was distributed farther from the acid fuchsin-stained red area in the normal samples than in the freeze-thaw-treated samples, and that some isolated Cs was distributed in the TW in areas where Cs was detected in the parenchyma cells, indicating that Cs exudes from the living parenchyma cells to the tracheid cell walls during Cs transportation in the ray parenchyma cells and then diffused into the cell walls. Together, these results indicate that the radial movement of minerals from the outer sapwood toward the heartwood of standing Japanese cedar tree trunks occurs through a combination of active transport by the parenchyma cells and diffusion in the cell walls of tracheids and parenchyma cells. 


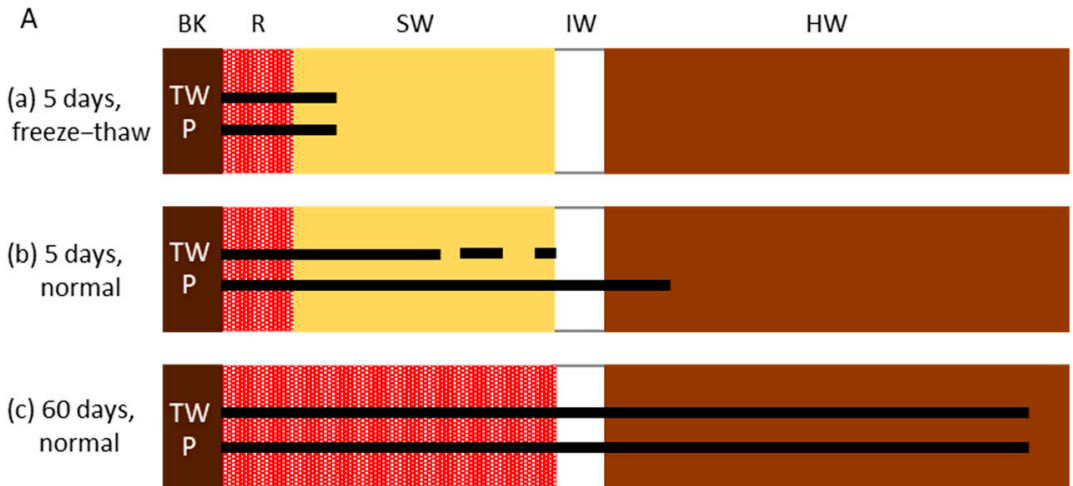

B

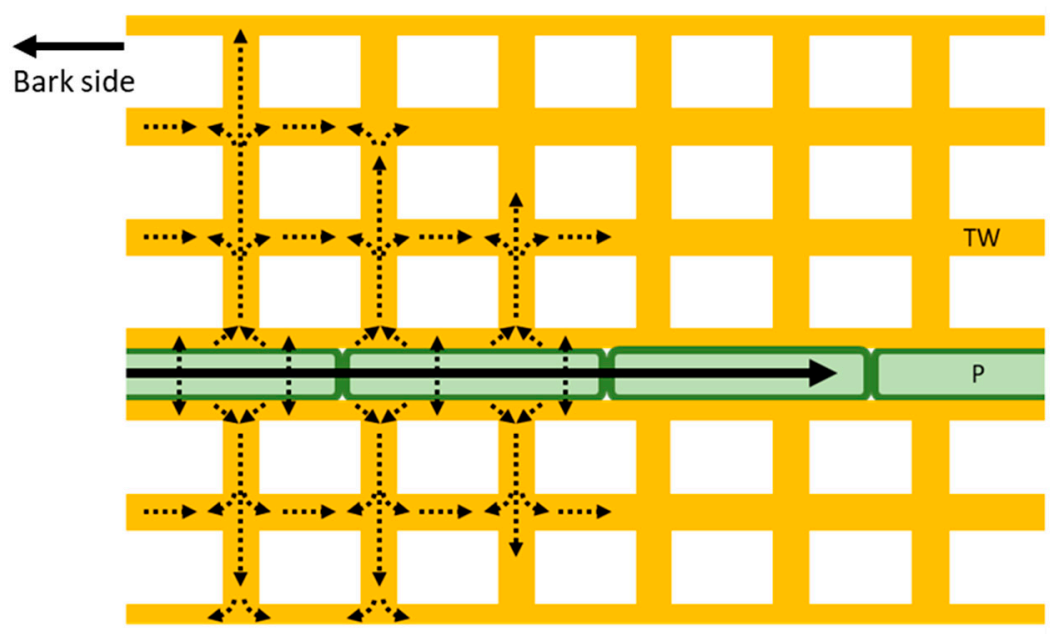

Figure 6. Schematic drawing of the radial movement of cesium (Cs) in the trunk of Japanese cedar (Cryptomeria japonica) trees. (A) Distribution of Cs in the xylem after (a) 5 days of injection in freeze-thaw-treated trees (showing movement by diffusion alone without living cells); (b) 5 days of injection in normal trees (showing movement by both active transport and diffusion); and (c) 60 days of injection in normal trees (showing movement by both active transport and diffusion). Bars and dots represent the distribution of Cs. (B) Subcellular movement of Cs in tracheids and ray parenchyma cells. Cs is transported symplasmically by the ray parenchyma cells (black arrow) and is then exuded and diffused into the tracheid cell walls (dotted arrows). BK, bark; R, red area stained by acid fuchsin; SW, sapwood; IW, intermediate wood; HW, heartwood; TW, tracheid cell wall; P, ray parenchyma cell.

\subsection{Effects of Season and the Injection Duration on Radial Mineral Movement}

Kuroda et al. [16] found that Cs was distributed at the border between the intermediate wood and heartwood and not in the inner heartwood after 4 days of Cs injection in winter, whereas in a similar experiment, Okada et al. [10] found that $\mathrm{Rb}$ was detected in the middle part of the heartwood at 10 days after injection (with an injection period of $<3$ days) in May. We previously suggested that this difference might have been caused by seasonal changes in the activity of ray parenchyma cells $[7,19,37]$. Therefore, in the present study, we injected Cs solution into the trunks of Japanese cedar trees in summer when the cell activity is higher and compared the Cs detection area in the parenchyma related structure (lumen and cell wall) between summer and winter to reveal whether seasonality affects the mineral transport ability.

We found that the Cs detection area of the 1-day injected sample was in the inner sapwood in summer than in winter, whereas that of the 3-h injected sample was almost the same between the two seasons. After 4 or 5 days of injection, Cs was distributed in the outer part of the heartwood (one to three annual rings from the border between the intermediate wood and the heartwood) in summer but was not detected beyond one annual ring from the border between the intermediate wood and 
the heartwood in winter. While this difference is small, these results provide interesting preliminary evidence to suggest that ray parenchyma cells can transport minerals faster in summer than in winter. Therefore, this seasonality in function should be verified in the future.

The Cs distribution was also analyzed in 60-day injected samples in summer to clarify the effect of a long period of mineral uptake on radial mineral movement. At the end of the injection period, the red area stained by acid fuchsin was widely distributed in the sapwood but had not spread into the intermediate wood or the heartwood. By contrast, Cs was distributed in the sapwood, intermediate wood, and part of the heartwood. This tendency was the same for the mature 35-year-old tree and the young 10-year-old tree and indicates that Cs is selectively moved across the intermediate wood into the heartwood. Since there are no living cells in the heartwood [19,38], Cs must have moved in the heartwood by diffusion. Thus, Cs was transported from the sapwood to the intermediate wood through a combination of active transport by parenchyma cells and diffusion, and then moved to the inner intermediate wood and the heartwood by diffusion. By contrast, it seems that there was a barrier in the intermediate wood to the diffusion of acid fuchsin. Heartwood substances accumulate in the intermediate wood and heartwood during heartwood formation, which may have played a role in forming this barrier. Therefore, it would be interesting to clarify the selective transport of chemicals in relation to heartwood formation.

\section{Conclusions}

It is difficult to elucidate the physiological phenomena that occur inside large trees developed heartwood. Thus, even though "facts" around this are written in textbooks, the actual state of these phenomena has not been demonstrated experimentally. One such phenomenon is the mechanism of mineral movement in a radial direction in the trunks of trees. Here, we used a method that allowed us to investigate this phenomenon as close as in living trees, which showed that the radial movement of minerals in the trunks occurs through a combination of active transport by ray parenchyma cells and passive diffusion. Moreover, we provided new evidence that minerals are transported in the parenchyma cells symplasmically and then exude and diffuse apoplasmically.

The heartwood of trees accumulates various minerals as a result of prolonged uptake, and in Japanese cedar, the ratio of minerals in the heartwood varies among clones and cultivars. In particular, the heartwood has a large amount of potassium with a high moisture content in some individuals and a small amount of potassium with a low moisture content in others, which poses a problem in the utilization of wood. The mechanism behind this difference has remained a mystery for more than 100 years $[39,40]$, but our finding that mineral movement occurs through a combination of symplasmic and apoplasmic transport combined with the fact that Cs moves to the heartwood whereas acid fuchsin does not may help us to elucidate this. Understanding these phenomena in large, living trees is also important for understanding the life strategy of long-lived trees.

Author Contributions: Conceptualization and design, K.K.; methodology and investigation, K.K., K.Y. and Y.I.; writing-original draft preparation, K.K.; writing-review and editing, K.K., K.Y. and Y.I.; funding acquisition, K.K. All authors have read and agreed to the published version of the manuscript.

Funding: This work was supported by JSPS KAKENHI (Grant Numbers JP25292110, JP16H04936, JP18H02258), and by the Support program of FFPRI for researchers having family obligations.

Acknowledgments: We appreciate the editors and anonymous reviewers for their helpful comments on the manuscript.

Conflicts of Interest: The authors declare no conflict of interest.

\section{References}

1. Tyree, M.T.; Zimmermann, M.H. Xylem Structure and the Ascent of Sap; Springer: Berlin, Germany, 2002.

2. Holbrook, N.M.; Zwieniecki, M.A. Integration of long distance transport systems in plants: Perspectives and prospects for future research. In Vascular Transport in Plants; Holbrook, N.M., Zwieniecki, M.A., Eds.; Elisevier Academic Press: San Diego, CA, USA, 2005; pp. 537-545. 
3. Sokołowska, K. Symplasmic transport in wood: The importance of living xylem cells Symplasmic Transport in Vascular Plants. In Symplasmic Transport in Vascular Plants; Sokołowska, K., Sowiński, P., Eds.; Springer Science-Business Media: New York, NY, USA, 2013; pp. 101-132.

4. Sauter, J.J.; Kloth, S. Plasmodesmatal frequency and radial translocation rates in ray cells of poplar (Populus $\times$ canadensis Moench 'robusta'). Planta 1986, 168, 377-380. [CrossRef] [PubMed]

5. Van Bel, A.J.E. Xylem-phloem exchange via the rays: The undervalued route of transport. J. Exp. Bot. 1990, 41, 631-644. [CrossRef]

6. Van der Schoot, C.; van Bel, A.J.E. Mapping membrane potential differences and dye-coupling in internodal tissues of tomato (Solanum lycopersicum L.). Planta 1990, 182, 9-21. [CrossRef] [PubMed]

7. Sauter, J.J.; van Cleve, B. Storage, mobilization and interrelations of starch, sugars, protein and fat in the ray storage tissue of poplar trees. Trees 1994, 8, 297-304. [CrossRef]

8. Chaffey, N.; Barlow, P. The cytoskeleton facilitates a three-dimensional symplasmic continuum in the long-lived ray and axial parenchyma cells of angiosperm trees. Planta 2001, 213, 811-823. [CrossRef] [PubMed]

9. Okada, N.; Hirakawa, Y.; Katayama, Y. Application of activable tracers to investigate radial movement of minerals in the stem of Japanese cedar (Cryptomeria japonica). J. Wood Sci. 2011, 57, 421-428. [CrossRef]

10. Okada, N.; Hirakawa, Y.; Katayama, Y. Radial movement of sapwood-injected rubidium into heartwood of Japanese cedar (Cryptomeria japonica) in the growing period. J. Wood Sci. 2012, 58, 1-8. [CrossRef]

11. Sokołowska, K.; Zagórska-Marek, B. Symplasmic, long-distance transport in xylem and cambial regions in branches of Acer pseudoplatanus (Aceraceae) and Populus tremula $\times$ P. tremuloides (Salicaceae). Am. J. Bot. 2012, 99, 1745-1755. [CrossRef]

12. Spicer, R. Symplasmic networks in secondary vascular tissues: Parenchyma distribution and activity supporting long-distance transport. J. Exp. Bot. 2014, 65, 1829-1848. [CrossRef]

13. Pfautsch, S.; Renard, J.; Tjoelker, M.G.; Salih, A. Phloem as capacitor: Radial transfer of water into xylem of tree stems occurs via symplastic transport in ray parenchyma. Plant Physiol. 2015, 167, 963-971. [CrossRef]

14. Kuroda, K.; Yamashita, K.; Fujiwara, T. Cellular level observation of water loss and the refilling of tracheids in the xylem of Cryptomeria japonica during heartwood formation. Trees 2009, 23, 1163-1172. [CrossRef]

15. Kuroda, K.; Fujiwara, T.; Imai, T.; Takama, R.; Saito, K.; Matsushita, Y.; Fukushima, K. The cryo-TOF-SIMS/SEM system for the analysis of the chemical distribution in freeze-fixed Cryptomeria japonica wood. Surf. Interface Anal. 2013, 45, 215-219. [CrossRef]

16. Kuroda, K.; Yamane, K.; Itoh, Y. Cellular level in planta analysis of radial movement of artificially injected caesium in Cryptomeria japonica xylem. Trees 2018, 32, 1505-1517. [CrossRef]

17. Kuroda, K.; Kagawa, A.; Tonosaki, M. Radiocesium concentrations in the bark, sapwood and heartwood of three tree species collected at Fukushima forests half a year after the Fukushima Dai-ichi nuclear accident. J. Environ. Radioact. 2013, 122, 37-42. [CrossRef]

18. Ohashi, S.; Kuroda, K.; Takano, T.; Suzuki, Y.; Fujiwara, T.; Abe, H.; Kagawa, A.; Sugiyama, M.; Kubojima, Y.; Zhang, C.; et al. Temporal trends in 137Cs concentrations in the bark, sapwood, heartwood, and whole wood of four tree species in Japanese forests from 2011 to 2016. J. Environ. Radioact. 2017, 178-179, 335-342. [CrossRef] [PubMed]

19. Nobuchi, T.; Kuroda, K.; Iwata, R.; Harada, H. Cytological study of the seasonal features of heartwood formation of sugi (Cryptomeria japonica D. Don). Mokuzai Gakkaishi 1982, 28, 669-676.

20. Nobuchi, T.; Harada, H. Physiological features of the 'white zone' of sugi (Cryptomeria japonica D. Don)—Cytological structure and moisture content. Mokuzai Gakkaishi 1983, 29, 824-832.

21. Nakada, R.; Fujisawa, Y.; Hirakawa, Y. Soft X-ray observation of water distribution in the stem of Cryptomeria japonica D. Don. I: General description of water distribution. J. Wood Sci. 1999, 45, 188-193. [CrossRef]

22. Nakaba, S.; Arakawa, I.; Morimoto, H.; Nakada, R.; Bito, N.; Imai, T.; Funada, R. Agatharesinol biosynthesis-related changes of ray parenchyma in sapwood sticks of Cryptomeria japonica during cell death. Planta 2016, 243, 1125-1236. [CrossRef]

23. Sano, Y.; Okamura, Y.; Utsumi, Y. Visualizing water-conduction pathways of living trees: Selection of dyes and tissue preparation methods. Tree Physiol. 2005, 25, 269-275. [CrossRef]

24. Umebayashi, T.; Utsumi, Y.; Koga, S.; Inoue, S.; Shiiba, Y.; Arakawa, K.; Matsumura, J.; Oda, K. Optimal conditions for visualizing water-conducting pathways in a living tree by the dye injection method. Tree Physiol. 2007, 27, 993-999. [CrossRef] [PubMed] 
25. Umebayashi, T.; Utsumi, Y.; Koga, S.; Inoue, S.; Fujikawa, S.; Arakawa, K.; Matsumura, J.; Oda, K. Conducting pathways in north temperate deciduous broadleaved trees. IAWA J. 2008, 29, 247-263. [CrossRef]

26. Kudo, K.; Yasue, K.; Hosoo, Y.; Funada, R. Relationship between formation of earlywood vessels and leaf phenology in two ring-porous hardwoods, Quercus serrata and Robinia pseudoacacia, in early spring. J. Wood Sci. 2015, 61, 455-464. [CrossRef]

27. Kudo, K.; Usumi, Y.; Kuroda, K.; Yamagishi, Y.; Nabeshima, E.; Nakaba, S.; Yasue, K.; Takata, K.; Funada, R. Formation of new networks of earlywood vessels in seedlings of the deciduous ring-porous hardwood Quercus serrata in springtime. Trees 2018, 32, 725-734. [CrossRef]

28. Steponkus, P.L.; Lynch, D.L. Freeze/thaw-induced destabilization of the plasma membrane and the effects of cold acclimation. J. Bioenerg. Biomembr. 1989, 21, 21-41. [CrossRef] [PubMed]

29. Uemura, M.; Steponkus, P.L. Effect of cold acclimation on membrane lipid composition and freeze induced membrane destabilization. In Plant Cold Hardiness: Molecular Biology, Biochemistry, and Physiology; Li, P.H., Chen, T.H.H., Eds.; Plenum Press: New York, NY, USA, 1998; pp. 171-179.

30. Yamada, T.; Kuroda, K.; Jitsuyama, Y.; Takezawa, D.; Arakawa, K.; Fujikawa, S. Roles of the plasma membrane and the cell wall in the responses of plant cells to freezing. Planta 2002, 215, 770-778. [CrossRef]

31. Fujikawa, S.; Kuroda, K.; Fukazawa, K. Ultrastructural study of deep supercooling of xylem ray parenchyma cells from Styrax obassia. Micron 1994, 25, 241-252. [CrossRef]

32. Fujikawa, S.; Kuroda, K.; Jitsuyama, Y.; Sano, Y.; Ohtani, J. Freezing behavior of xylem ray parenchyma cells in softwood species with differences in the organization of cell walls. Protoplasma 1999, 206, 31-40. [CrossRef]

33. Nakaba, S.; Morimoto, H.; Arakawa, I.; Yamagishi, Y.; Nakada, R.; Funada, R. Responses of ray parenchyma cells to wounding differ between earlywood and latewood in the sapwood of Cryptomeria japonica. Trees 2017, 31, 27-39. [CrossRef]

34. Kim, J.S.; Awano, T.; Yoshinaga, A.; Takabe, K. Immunolocalization and structural variations of xylan in differentiating earlywood tracheid cell walls of Cryptomeria japonica. Planta 2010, 232, 817-824. [CrossRef]

35. Kim, J.S.; Awano, T.; Yoshinaga, A.; Takabe, K. Ultrastructure of the innermost surface of differentiating normal and compression wood tracheids as revealed by field emission scanning electron microscopy. Planta 2012, 235, 1209-1219. [CrossRef] [PubMed]

36. Fujikawa, S.; Ishida, S. Ultrastructure of ray parenchyma cell walls of softwood. Mokuzai Gakkaishi 1975, 21, 445-456.

37. Nakada, R.; Fukatsu, E. Seasonal variation of heartwood formation in Larix kaempferi. Tree Physiol. 2012, 32, 1497-1508. [CrossRef] [PubMed]

38. IAWA (Committee on Nomenclature International Association of Wood Anatomists). Multilingual Glossary of Terms Used in Wood Anatomy; Verlagsanstalt Buchdrucherei Konkordia: Winterthur, Switzerland, 1964.

39. Fujioka, M.; Takashi, K. Sugi Shinzaishoku Koppen ni Kansuru Kenkyu (On the Cause of the Darkening of the Heartwood of Cryptomeria Japonica Don). For. Exp. Stn. Bull. FFPRI 1918, 16, 1-78. (In Japanese)

40. Fujioka, M.; Takashi, K. On the Cause of the Darkening of the Heartwood of Cryptomeria Japonica Don. J. For. 1921, 19, 844-866.

(C) 2020 by the authors. Licensee MDPI, Basel, Switzerland. This article is an open access article distributed under the terms and conditions of the Creative Commons Attribution (CC BY) license (http://creativecommons.org/licenses/by/4.0/). 